\title{
Climatic forcing before, during, and after the 8.2 Kyr B.P. global cooling event
}

\author{
Devendra Lal ${ }^{1, *}$, William G Large ${ }^{2}$ and Stephan G Walker ${ }^{1}$ \\ ${ }^{1}$ Scripps Institution of Oceanography, GRD 0244, La Jolla, CA 92093, USA. \\ ${ }^{2}$ National Center for Atmospheric Research, Boulder, Colorado, CO 8030\%, USA. \\ *e-mail:dlal@ucsd.edu
}

This paper attempts at full characterization of the unique global 8.2 Kyr B.P. cooling event. Significant atmospheric cooling started during 9.5-8.5 Kyr B.P. when the Sun was extremely quiet during three periods of $\sim 50-100$ years. The flood of melt water in the N. Atlantic from glacial lakes during the demise of the Laurentide ice sheet, starting at $\sim 8.5 \mathrm{Kyr}$ B.P., adds to the atmospheric cooling. Climatic forcing events occurred at $8.5 \mathrm{Kyr}$ B.P., at $8.2 \mathrm{Kyr}$ B.P. and finally at $8.06 \mathrm{Kyr}$ B.P., leading to concurrent increases or decreases in the atmospheric $\Delta^{14} \mathrm{C}$ levels, completely consistent with the climatic forcing proposed here.

\section{Introduction}

The largest abrupt climatic event at $8.2 \mathrm{Kyr}$ B.P. has drawn considerable attention of climate modelers (Alley and Agustsdottir 2005; Morrill and Jacobsen 2005; Rohling and Palike 2005), in view of its global character and magnitude and occurrence in the Holocene, but it has not yet been fully characterized. The GISP2 $\delta^{18} \mathrm{O}$ record shows a distinct earlier cooling period during 8.5-8.3 Kyr B.P., consistent with the date $(\sim 8.5 \pm 0.3 \mathrm{Kyr}$ B.P. $)$ obtained for the outburst drainage from glacial lakes Agassiz and Ojibway during the terminal demise of the Laurentide ice sheet (Barber et al 1999; Rohling and Palike 2005). Atmospheric cooling however began about thousand years earlier (Lal et al 2005), during periods of low solar activity. We show that by correlating the atmospheric $\delta^{18} \mathrm{O}$ record in Greenland Summit ice with (i) the tree ring cosmogenic ${ }^{14} \mathrm{C}$ record during 10,000 $7000 \mathrm{yr}$ B.P. and (ii) the information on levels of solar activity during the same period, based on cosmogenic ${ }^{14} \mathrm{C}$ produced in the Greenland Summit ice event, we are able to fully characterize the cooling event in terms of its climate forcing. We discuss below the sequence of events which caused the abrupt cooling at $\sim 8.2 \mathrm{Kyr}$ B.P.

\section{Records of $\Delta^{14} \mathbf{C}$ in tree rings, and of $\delta^{18} \mathrm{O}$ in GISP2 ice, and cosmogenic ${ }^{14} \mathrm{C}$ in Summit ice from Greenland}

Based on measurements of cosmic ray flux, derived from cosmogenic in situ produced ${ }^{14} \mathrm{C}$ in the GISP2 ice core, it has been deduced (Lal et al 2005) that during 9.5-8.5 Kyr B.P., solar activity was extremely low for century scale periods, similar to that during Maunder Minimum (1645-1715 A.D.). The ice record is based on an observed increase in the cosmogenic in situ produced ${ }^{14} \mathrm{C}$ (and therefore in the cosmic ray flux) in four samples of ages between 8.6 and $9.7 \mathrm{Kyr}$ B.P. by a factor of $2.3 \pm 0.31$ (Lal et al 2005). This is a direct inference based on the measurement of cosmic ray flux at the GISP2 site. The polar cosmic ray flux is related to the full interplanetary cosmic ray flux in the 1 A.U. interplanetary space, and is inversely correlated with solar activity. It is not influenced by any changes in the geomagnetic field strength or climate. Based on the theoretical model for cosmic

Keywords. $8.2 \mathrm{Kyr}$ cooling event; paleoclimate; atmospheric ${ }^{14} \mathrm{C}$; atmospheric $\delta^{18} \mathrm{O}$; enhanced oceanic mixing; cosmogenic ${ }^{14} \mathrm{C}$ in ice; atmospheric sciences; climate; modeling. 

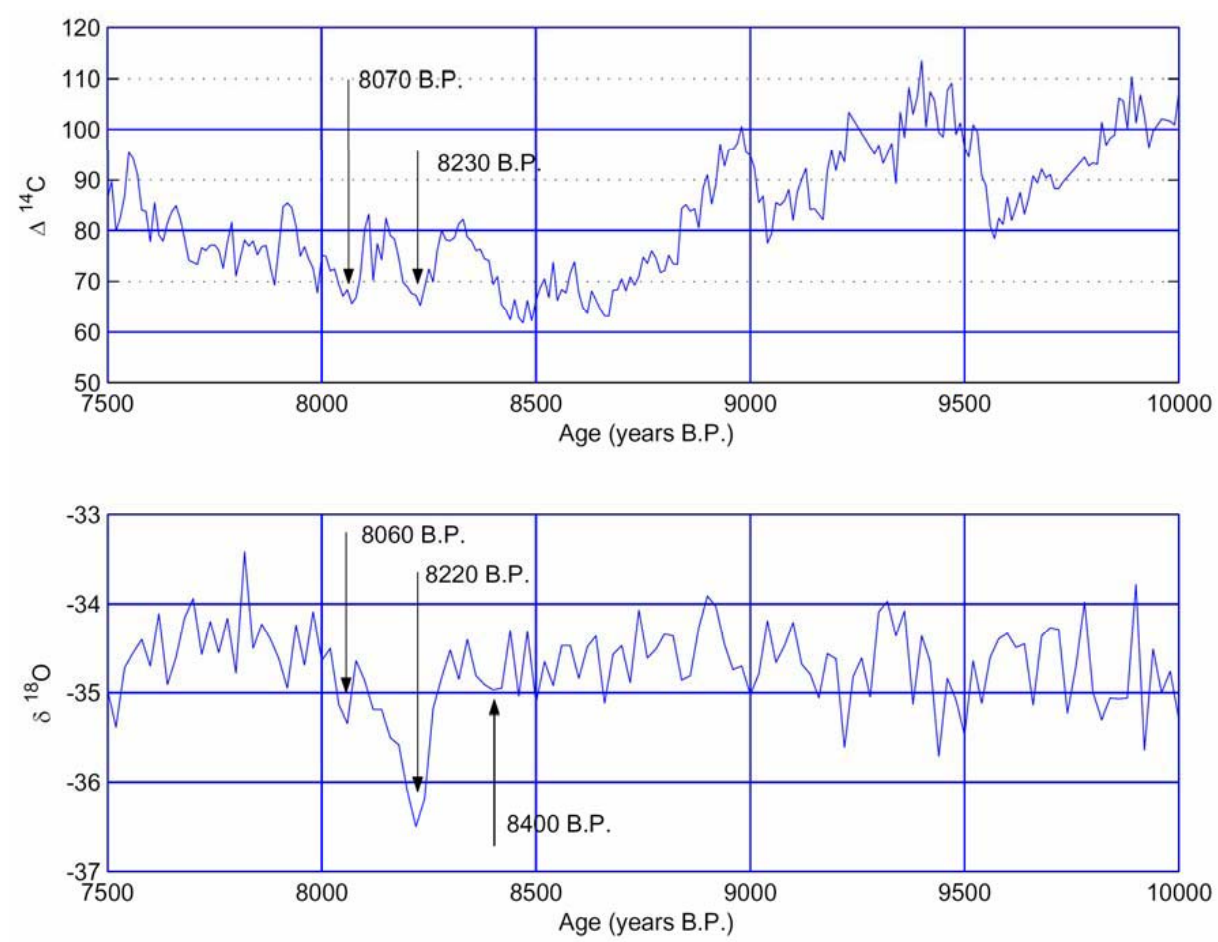

Figure 1. The upper figure shows the unfiltered $\Delta^{14} \mathrm{C}$ record in tree rings (Stuiver et al 1998) for the time period 10,000-7500 yr B.P. The lower figure shows the unfiltered $\delta^{18} \mathrm{O}$ values in Greenland Summit ice (Greenland Ice Sheet Project $2)$, measured by Stuiver et al (1995) for the same period. The ages of minima in the $\Delta^{14} \mathrm{C}$ and $\delta^{18} \mathrm{O}$ records are marked.

ray modulations by solar activity, the measured cosmic ray flux is theoretically consistent with essentially no sunspots for periods of 50-100 years for each of the samples analyzed. A support for this inference is found in the tree ring atmospheric $\Delta^{14} \mathrm{C}$ record which shows three $\Delta^{14} \mathrm{C}$ peaks (figure 1). It should be noted here that the tree ring record cannot be used by itself to determine the level of solar activity in the past, since it is influenced by changes in climate and geomagnetic field intensity (Lal et al 2005). Nevertheless, the three $\Delta^{14} \mathrm{C}$ excursions seen in figure 1 at $\sim 9.43,9.24$ and $8.98 \mathrm{Kyr}$ B.P. are comparable to that observed during the Maunder Minimum (Stuiver and Braziunas 1989), $\sim 20 \%$, and clearly support the inference that the $2 \times$ higher cosmic ray flux during the deposition of the four ice samples (Lal et al 2005 ) was due to century scale periods when there were essentially no sunspots, as observed during the Maunder Minimum.

One would expect significant climatic changes during 9.5-8.5 Kyr B.P. when the Sun was very quiet for three periods of about 50-100 years each. Historical records for the past 1800 years, including the Maunder Minimum, show that changes in solar brightness, although amounting to less than $1 \%$, are well correlated with changes in terrestrial climatic records (Lean et al 1995; Pang and Yau 2002). Based on a large number of observations of climate indicators in ocean sediments and in polar ice covering the past 15-20 Kyr, Bond et al (2001) have presented extensive records of drift ice and ocean surface temperatures, as recorded by a few mineral tracers and planktonic $\delta^{18} \mathrm{O}$, respectively, and compared these records with smoothed and detrended records of ${ }^{14} \mathrm{C}$ in tree rings (and ${ }^{10} \mathrm{Be}$ ocean sediments). A common feature of the records is that periods of strong ice drift are related to colder epochs, and closely match large changes in ${ }^{14} \mathrm{C}$, suggesting that periods of increased ice drift are related to periods of reduced solar output. We note that the Summit $\delta^{18} \mathrm{O}$ record in ice shows clear depressions of temperature during the three positive excursions in the tree ring atmospheric $\Delta^{14} \mathrm{C}$ record, corresponding to low solar activity (figure 2 , based on data in figure 1 ) at $\sim 9.43,9.24$ and $8.98 \mathrm{Kyr}$ B.P. The high-resolution measurements of $\delta^{18} \mathrm{O}$ in a stalagmite (Neff et al 2001) from Oman point to periods of low solar activity including 9.0 Kyr B.P. (which matches the positive excursion in $\Delta^{14} \mathrm{C}$ in figure 1 ). A number of other observations (Bond et al 2001) show that colder climates were related in the past to higher ${ }^{14} \mathrm{C}$ production rates, implying a causal relation to a quieter Sun (which corresponds to reduced solar modulation of the interstellar cosmic ray flux). Thus it seems fairly certain that colder periods generally match periods of low solar activity. 

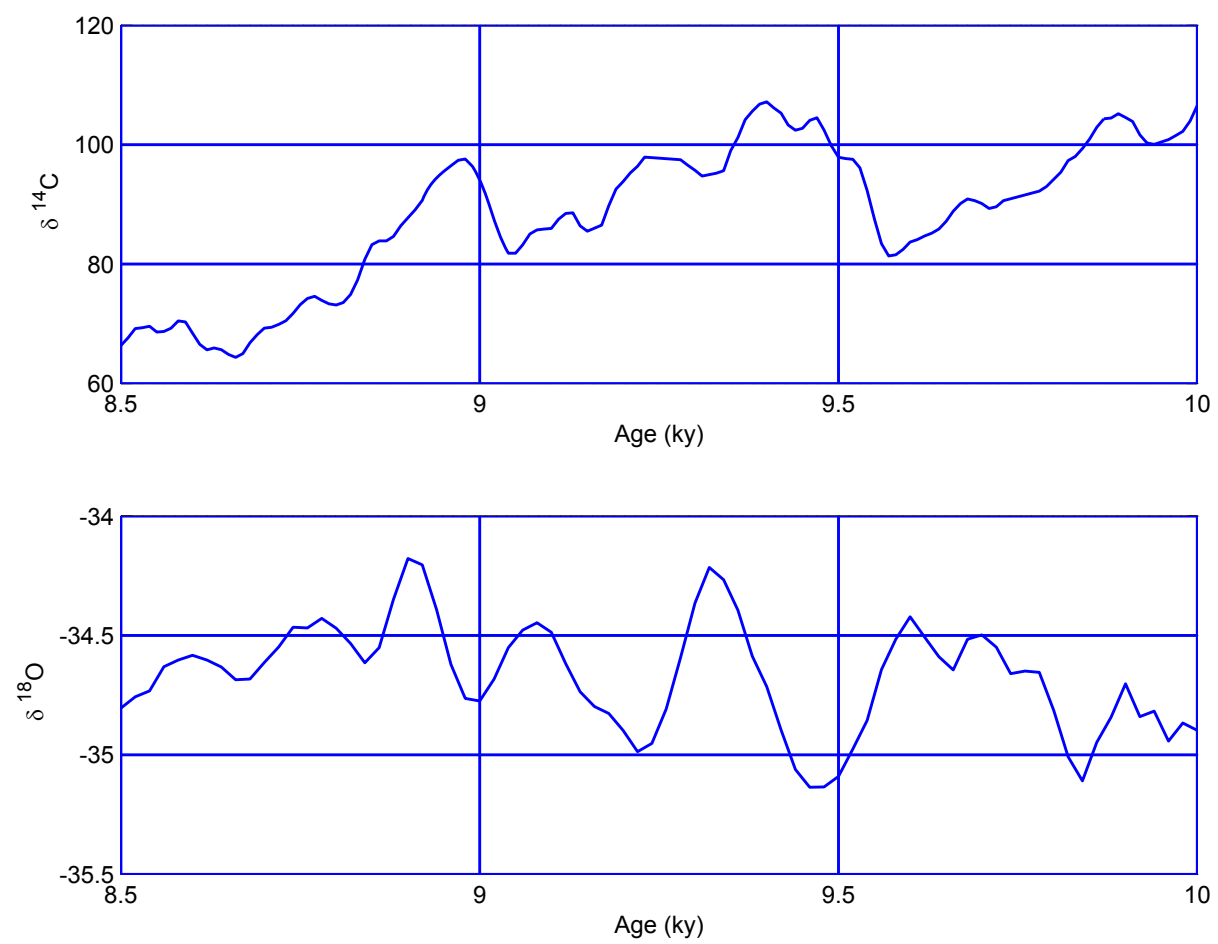

Figure 2. Filtered $\Delta^{14} \mathrm{C}$ record in the tree rings (Stuiver et al 1998) for the low solar activity epoch, 10,000-8500 yr B.P. is shown in the upper figure; the corresponding $\delta^{18} \mathrm{O}$ record in the Greenland Summit ice (Greenland Ice Sheet Project 2), measured by Stuiver et al (1995), is shown in the lower figure.

The $8.2 \mathrm{Kyr}$ event is seen in both the $\delta^{18} \mathrm{O}$ and $\Delta{ }^{14} \mathrm{C}$ records, matching well in shape in the cooling as well as the recovery periods. There occurs a concurrent decrease in the $\Delta^{14} \mathrm{C}$ record during the cooling event. This decrease can only be explained if the cooling event was caused by increased vertical mixing in the oceans, which could have resulted from increased wind speeds, causing an episodic turn over of the upper oceanic layers. This is in fact supported by wind simulation studies discussed below, and is consistent with the expected change in $\Delta^{14} \mathrm{C}$. However, if the GISP2 chronology was in error, so that in fact there occurred a concurrent increase in atmospheric tree ring $\Delta^{14} \mathrm{C}$ record during the cooling event (which is possible to entertain by shifting the GISP 2 chronology by +80 years), then the increase in $\Delta^{14} \mathrm{C}$ would be due to spreading of melt water on the ocean surface. The latter would decrease the vertical mixing rate of the oceans, expected due to slowing down of NADW formation and also due to freshening of the surface waters, which would cause stable stratification of the mixed layer in the N. Atlantic (Worthington 1968; Berger and Killingley 1982; Berger 1987; Rahmstorf 1995).

Note that the event chronology in figure 1 is based on the Greenland Ice Project 2 (GISP2) chronology. If however, we shift the GISP2 chronology by $\pm(1$ and $2 \%)$, the relations between $\delta^{18} \mathrm{O}$ and $\Delta^{14} \mathrm{C}$ records would be severely mis-aligned, suggesting that the GISP2 chronology is fairly accurate within 20 years. In the period of interest, as discussed below, this is consistent with the new Greenland chronology (Rasmussen et al 2006).

\section{Sequence of events since 9500 B.P. leading to the $8200 \mathrm{yr}$ B.P. cooling event}

We can now summarize the sequence of climatic events before and around the $8.2 \mathrm{Kyr}$ cooling event:

(i) The atmosphere cooled (Lal et al 2005) for a total period $\geq 200$ years during $9.5-8.5 \mathrm{Kyr}$ B.P. due to three episodes of solar quiet periods (figure 1), which was followed by

(ii) release of flood of melt waters from the glacial lakes Agassiz and Ojibway (Barber et al 1999; Rohling and Palike 2005) during 8.5-8.3 Kyr B.P. (figure 1 shows the conspicuous cooling event in the GISP2 $\delta^{18} \mathrm{O}$ record during 8.5-8.3 Kyr B.P. with a peak at $\sim 8.4 \mathrm{Kyr}$ B.P.), which caused a significant increase in atmospheric $\Delta^{14} \mathrm{C}$ by $\sim 12-14 \%$ o (figure 1 ). This is expected since freshening of the surface waters would cause stable stratification of the mixed layer in the N. Atlantic (Worthington 1968; Berger and Killingley 1982; Berger 1987; Rahmstorf 1995), and also the slow down of 
NADW formation, both leading to a reduction of exchange of carbon dioxide between the atmosphere and the ocean. Glacial outburst was followed by

(iii) an abrupt temperature decrease at $\sim 8.3 \mathrm{Kyr}$ B.P. coincident with a synchronous decrease (within 10 years) in the atmospheric $\Delta^{14} \mathrm{C}$ (figure 1), followed by

(iv) another cooling event at $8.08-8.0 \mathrm{Kyr}$ B.P. (figure 1), before full recovery of the $8.2 \mathrm{Kyr}$ B.P. event, again coincident with a consequent decrease in the atmospheric $\Delta^{14} \mathrm{C}$.

The significant concurrent decreases in atmospheric $\Delta^{14} \mathrm{C}$ during phases (iii) and (iv) would be expected only if vertical oceanic mixing was enhanced during these periods, bringing deeper waters to surface, lowering ${ }^{14} \mathrm{C} /{ }^{12} \mathrm{C}$ ratios. Note that increased vertical mixing also lowers the atmospheric temperature, serving as a positive feedback in maintaining the $8.2 \mathrm{Kyr}$ cooling event. In order to check on the magnitude of changes expected from enhanced vertical mixing in the oceans during colder periods, we have made runs with the NCAR Climate System model, which is discussed below.

\section{Effects of increased strength of global winds during cold periods}

It is generally accepted that open ocean and coastal upwelling are the principal forcing for $\sim 80-90 \%$ of the global oceanic productivity (Summerhayes et al 1995). In mid-ocean or in the coastal regions, wind stress on the ocean surface causes horizontal divergence, which is compensated by the upwelling of deeper waters. Winds affect upwelling in two ways, through Ekman pumping at the coast and through the additive effect of wind-stress curl. In order to quantitatively see the effect of increased wind speeds, we carried out model runs with the NCAR Climate System model (Doney et al 1998; Gent et al 1998) for the case of $2 \times$ global wind stress, corresponding to change in global winds by $\sqrt{ } 2$.

The temperature difference $(\Delta T)$, between $2 \times$ wind stress and the control run are plotted here for four depth levels, 6.0, 38.42, 93.57 and $527.7 \mathrm{~m}$ in figure 3 . The surface temperatures at $6 \mathrm{~m}$ depth are seen to decrease by $1-2^{\circ} \mathrm{C}$ and $0.5-1^{\circ} \mathrm{C}$ respectively, in about $29 \%$ and $38 \%$ of the global ocean area. Cooling in the $70-90^{\circ} \mathrm{N}$ and $>60^{\circ} \mathrm{S}$ regions are much smaller $\left(<0.25^{\circ} \mathrm{C}\right)$. Appreciable differential cooling persists to depths of $93.57 \mathrm{~m}$. Regions with $\Delta \mathrm{T}$ values of $1-2^{\circ} \mathrm{C}$ exist down to depths of $527.7 \mathrm{~m}$. The results of this simulation allow for the inferred $8.2 \mathrm{Kyr}$ B.P. cooling of Greenland temperatures.
The expected decreases in the atmospheric $\Delta^{14} \mathrm{C}$ can be estimated from the measured pre-bomb natural ${ }^{14} \mathrm{C}$ levels (Key et al 2004) for the three principal oceans Pacific, Atlantic and Indian. If we mix well the top $100,200,300,500,700$ and $1000 \mathrm{~m}$ of the ocean, we expect decreases in the atmospheric $\Delta^{14} \mathrm{C}$ values by $9.5,18.1,27.2,46.0$, 69.2 and $100.5 \%$, respectively. Considering that the vertical mixing is not homogeneous over the oceans (figure 3 ), the observed decrease of $\sim 15 \%$ o in $\Delta^{14} \mathrm{C}$ during the $8.2 \mathrm{Kyr}$ B.P. event is qualitatively consistent with the model run for the $2 \times$ global wind stress, which shows that wind stress has caused widespread global deep vertical mixing to depths of $\sim 500 \mathrm{~m}$, leading to substantial temperature reduction even at depths of $93.57 \mathrm{~m}$.

\section{A consistent model for the forcing of the $8200 \mathrm{yr}$ B.P. event}

The foregoing shows that the events observed during 8.5-8.2 Kyr B.P. are presumably a natural consequence of forcing of climate by the existence of very low solar activity (Lal et al 2005) during 9.5-8.5 Kyr B.P., with additional forcing by the large flood of melt water in the N. Atlantic from glacial lakes during the terminal demise of the Laurentide ice sheet, beginning at $\sim 8.5 \mathrm{Kyr}$ B.P. (Barber et al 1999; Rohling and Palike 2005). So far we have based our inferences on the GISP2 chronology for the $\delta^{18} \mathrm{O}$ record. The depositional chronology of the ice samples analyzed is fairly well known since the layer thicknesses are reliable in the interval of time of interest, and there exist suitable tie points with U/Th chronology (Alley et al 1997; Cuffey and Clow 1997; Meese et al 1997; Hughen et al 2004). The thinning factors are not too dependent on the accumulation model (Cuffey and Clow 1997); they lie in the ranges: 2.2$2.5,3-3.5$ and 3.5-4.0 respectively for ice of ages $5 \mathrm{Kyr}$ and $10 \mathrm{Kyr}$ B.P. The cumulative estimates of errors in age assignment for ice of ages $<3 \mathrm{Kyr}$ B.P., 4-39 Kyr B.P. are $\sim 1 \%$ and $2 \%$ respectively (Meese et al 1997). GISP2 chronology is well tied to a few well-dated events within assigned errors. Two tie points (Hughen et al 2004) are: the termination of the Younger Dryas and the Heinrich 3 event at $\sim 30 \mathrm{Kyr}$ B.P. Hughen et al (2004) have commented on the absolute accuracy of the GISP2 chronology for the period 10-40 Kyr. They note that the U/Th dates for millennial scale events from Hulu Cave in eastern China and Villars Cave in southwest France correlate well with the GISP2 chronology.

In order to assess the dependence of the interpretation of the atmospheric $\delta^{18} \mathrm{O}$ on the age 


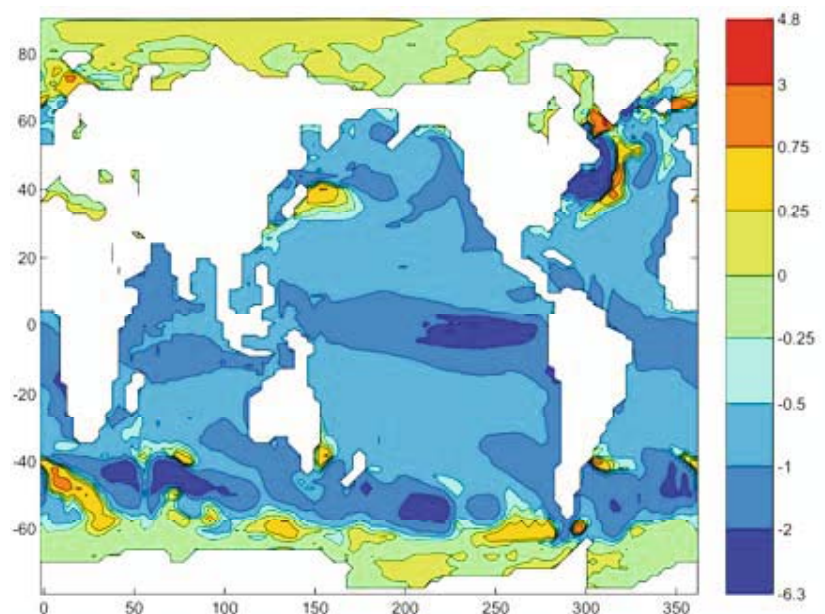

(a) $6.0 \mathrm{~m}$

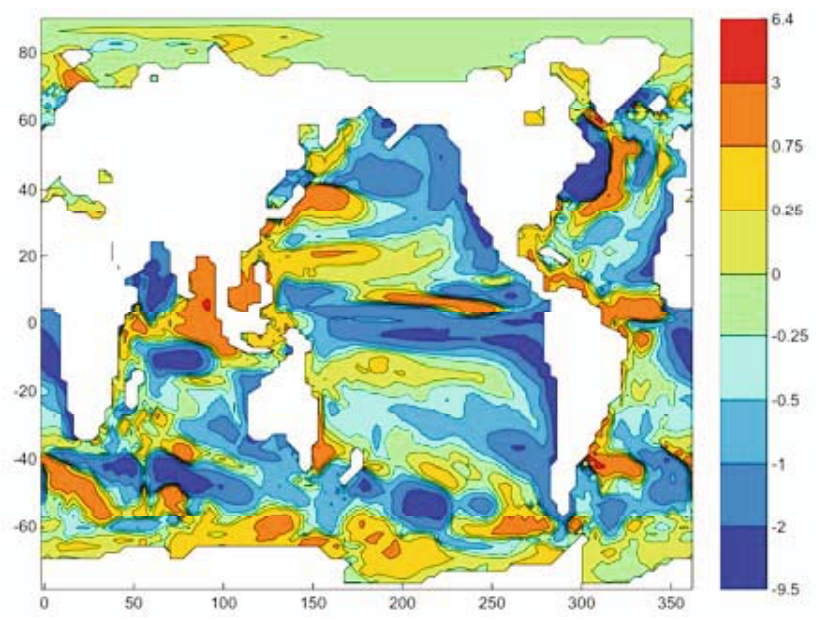

(c) $93.57 \mathrm{~m}$

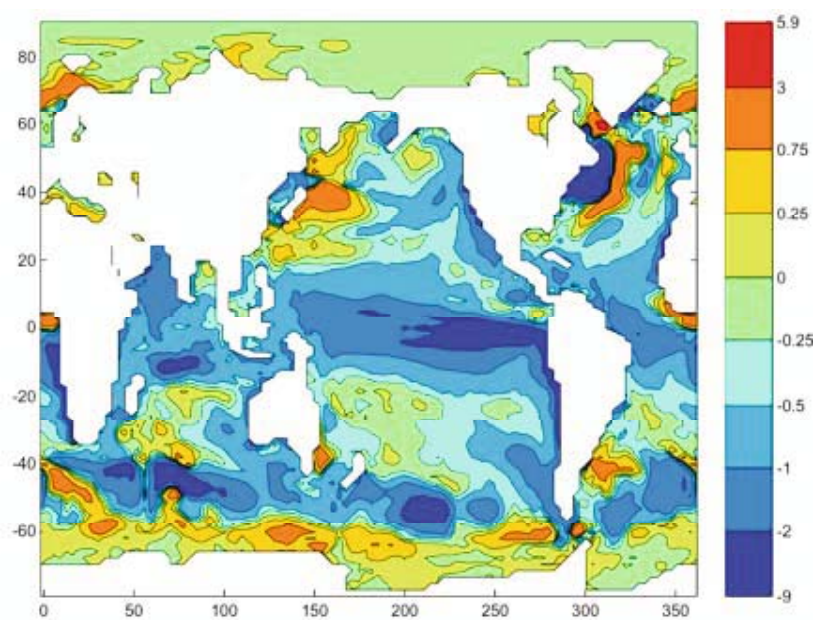

(b) $38.42 \mathrm{~m}$

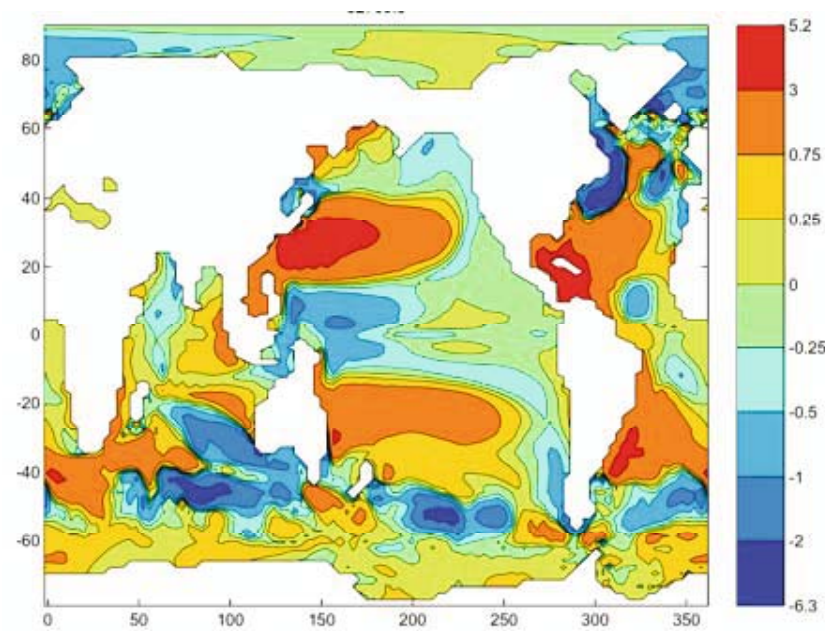

(d) $527.7 \mathrm{~m}$

Figure 3. Iso-contour profiles of temperature differences in global ocean at 4 depths, 6.0, 38.42, 93.57 and $527.7 \mathrm{~m}$, between $2 \times$ wind stress and the control runs with the ocean-atmosphere coupled NCAR Climate System Model (Doney et al 1998; Gent et al 1998).

assignment, we have plotted the $\delta^{18} \mathrm{O}$ record by displacing it by \pm 1 and $2 \%$ in figure 4 , along with the atmospheric $\Delta^{14} \mathrm{C}$ tree ring record. It becomes apparent from figure 4 that the match between the $\delta^{18} \mathrm{O}$ records during the $9.5-8.5 \mathrm{Kyr}$ B.P. when the Sun was extremely quiet during three periods of 50-100 years each, becomes very poor for the \pm 1 and $2 \%$ shifts in GISP2 ice chronology, sometimes showing higher $\delta^{18} \mathrm{O}$ values during the three positive excursions in $\Delta^{14} \mathrm{C}$ tree ring record. During the time interval, $8.5-8.0 \mathrm{Kyr}$ B.P., only the case of chronology shifted by $+1 \%$ seems to show some match between $\delta^{18} \mathrm{O}$ and $\Delta^{14} \mathrm{C}$ records at $\sim 8230$ B.P.; but other correlations are altered in sign: (i) the sign of the $\Delta^{14} \mathrm{C}$ change at $\sim 8.3 \mathrm{Kyr}$ is reversed, and (ii) during the positive excursions in $\Delta^{14} \mathrm{C}$ at $9.0 \mathrm{Kyr}$ B.P., the $\delta^{18} \mathrm{O}$ record shows a prominent warming.
Based on comparison of ${ }^{14} \mathrm{C}$ and ${ }^{10} \mathrm{Be}$ records in the GRIP core, Muscheler et al (2004) concluded that the timing of the mid-8.2 Kyr event was $\sim 8.15$ Kyr B.P., i.e., $\sim 70$ years earlier than that given by the GISP2 chronology (figure 1). A new chronology for the North Greenland Ice Core Project (NGRIP) and GRIP ice cores for the 7.9$14.8 \mathrm{Kyr}$ bracket has been presented by Rasmusson et al (2006). In the time interval of interest here, 10-8 Kyr B.P., the GISP2 chronology differs from NGRIP chronology by -20 to +38 years. The differences between NGRIP and GISP2 ages are $-38,-27,-9,21$ and 20 yrs respectively at 8.0, 8.5, 9.0, 9.5 and $10.0 \mathrm{Kyr}$. This corresponds to a shift in the GISP2 chronology by -33 years for the mid-8.2 Kyr event, and $\sim+20$ years at $\sim 9.5 \mathrm{Kyr}$. The new NGRIP chronology (Rasmusson et al 2006) suggests a shift of $\sim-30$ years in the GISP2 

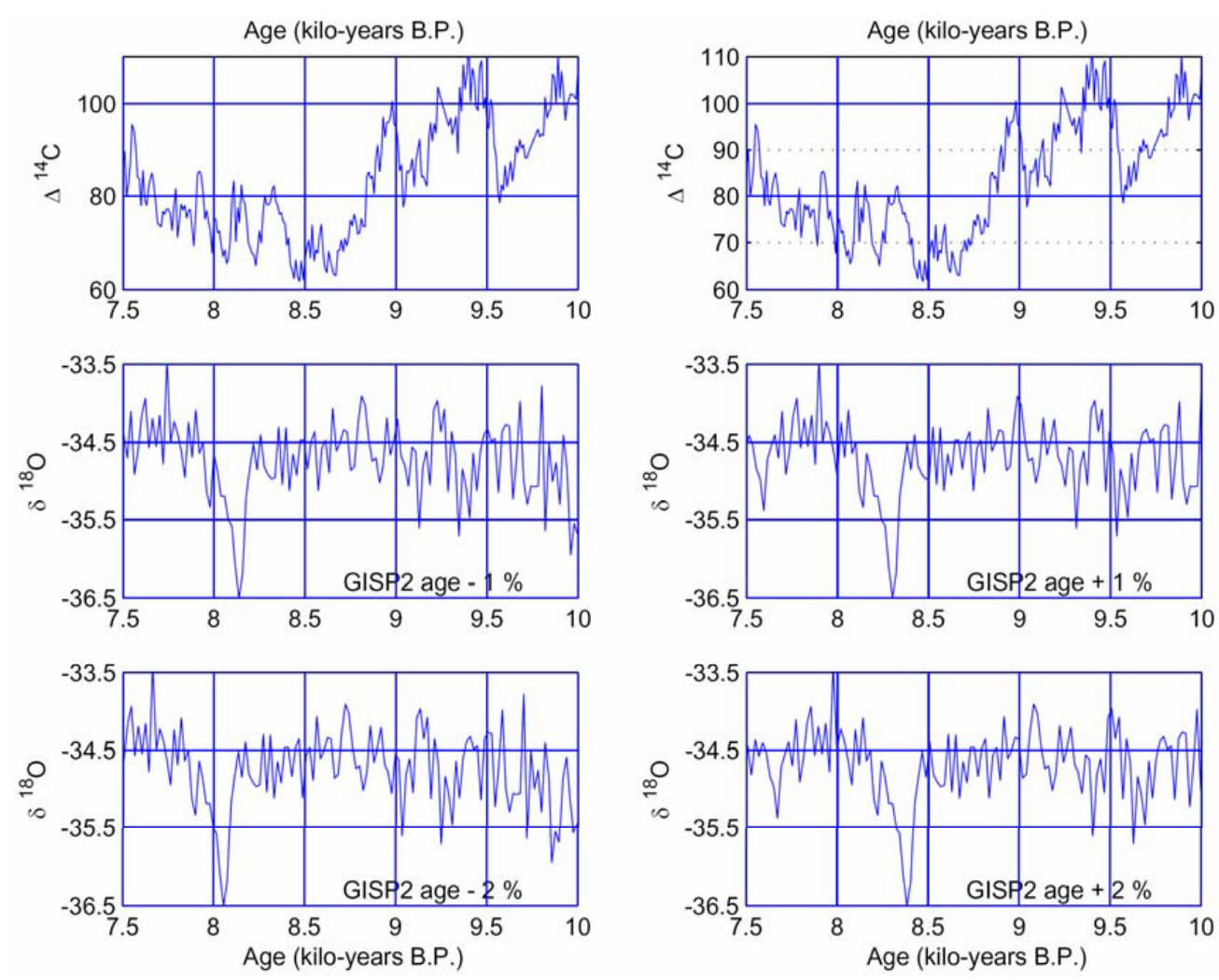

Figure 4. The top two figures show the $\Delta^{14} \mathrm{C}$ record in tree rings, reproduced from figure 1 , for the time period $10-7.5 \mathrm{Kyr}$ B.P. The other four figures show the measured $\delta^{18} \mathrm{O}$ values in Greenland Summit ice (Greenland Ice Sheet Project 2), as in figure 1 , but with the chronology shifted by \pm 1 and $\pm 2 \%$.

chronology at $\sim 8.2 \mathrm{Kyr}$. This does not significantly alter the scenario of events discussed above.

However as discussed above, we do see that a very consistent climate chronology is that based on the GISP2 $\delta^{18} \mathrm{O}$ chronology in the entire time range of 10-8 Kyr B.P., with a consistent pattern of relationships between tree ring $\Delta^{14} \mathrm{C}$ and GISP2 $\delta^{18} \mathrm{O}$ records, suggesting that the GISP2 chronology is correct within 20 years.

\section{Concluding remarks}

In conclusion, the data presented here show the combined effect of climatic cooling due to three low solar activity periods during 9.5-8.5 Kyr B.P. when the Sun was extremely quiet, and the large flood of melt water in the N. Atlantic from glacial lakes during the terminal demise of the Laurentide ice sheet, in contributing to the abrupt cooling event at $8.2 \mathrm{Kyr}$ B.P. The climatic impact of these events is clearly imprinted in the tree ring cosmogenic ${ }^{14} \mathrm{C}$ record during $10,000-7000$ yr B.P. The increase in $\Delta^{14} \mathrm{C}$ during $8.5-8.3 \mathrm{Kyr}$ B.P. is attributed to reduced atmosphere-ocean exchange rate due to slowing down of NADW formation, and also due to freshening of the surface waters. On the other hand, the concurrent decreases in atmospheric $\Delta^{14} \mathrm{C}$ at $8.2 \mathrm{Kyr}$ B.P. and $8.06 \mathrm{Kyr}$ B.P. are attributed to increased vertical mixing in the oceans, forced by strong large scale winds, especially during the $8.2 \mathrm{Kyr}$ B.P. cold period (increased vertical mixing serves as positive feedback due to bringing up cooler waters which further lower the atmospheric temperature), and release of lower ${ }^{14} \mathrm{C} /{ }^{12} \mathrm{C}$ ratio carbon from deeper layers of the ocean. The scenario presented here is supported by model calculations with NCAR Climate System Model, which show that even a global $2 \times$ wind stress $(\sqrt{ } 2 \times$ wind speed $)$ causes fairly extensive global vertical mixing to depths of $\geq 500 \mathrm{~m}$, and the observed distribution of natural (pre-bomb) levels of ${ }^{14} \mathrm{C}$ in the oceans (Key et al 2004).

\section{Acknowledgements}

We thank NSF-OPP Polar Programs, Wolf Berger, and Jeff Severinghaus for very helpful comments and advice.

\section{References}

Alley R B, Shuman C A, Meese D A, Gow A J, Taylor K C, Cuffey K M, Fitzpatrick J J, Grootes P M, Zielinski G A, Ram M, Spinelli G and Elder B 1997 Visual-stratigraphic 
dating of the GISP2 ice core: Basis, reproducibility, and application; J. Geophys. Res. - Oceans 102 $26,367-26,381$.

Alley R B and Agustsdottir A M 2005 The 8k event: cause and consequences of a major Holocene abrupt climate change; Quat. Sci. Rev. 24 1123-1149.

Barber D C et al 1999 Forcing of the cold event of 8,200 years ago by catastrophic drainage of the Laurentide lakes; Nature 400 344-348.

Berger W H and Killingley J S 1982 The Worthington effect and the origin of the Younger Dryas; J. Marine Res. 40 $27-38$.

Berger W H 1987 Ocean ventilation during the last 12,000 years: hypothesis of counterpoint deep water production; Marine Geol. 78 1-10.

Bond G, Kromer B, Beer J, Muscheler R, Evans M N, Showers W, Hoffmann S, Lotti-Bond R, Hajdas I and Bonani J 2001 Persistent solar influence on north Atlantic climate during the Holocene; Science 294 2130-2136.

Cuffey K M and Clow G D 1997 Temperature, accumulation, and ice sheet elevation in central Greenland through the last deglacial transition; J. Geophys. Res. - Oceans 102 26,383-26,396.

Doney S C, Large W G and Bryan F O 1998 Surface ocean fluxes and water mass transformation rates in the coupled NCAR climate system model; J. Climate 11 1420-1441.

Gent P R, Bryan F O, Danabasoglu G, Doney S, Large W R and McWilliams J C 1998 The NCAR climate system model global ocean component; J. Climate 11 1287-1306.

Hughen K, Lehman S, Southon J, Overpeck J, Marchal O, Herring $\mathrm{C}$ and Turnbull $\mathrm{J} 2004{ }^{14} \mathrm{C}$ activity and global carbon cycle over the past 50,000 years; Science $\mathbf{3 0 3}$ 202-207.

Key R M, Kozyr A, Sabine C L, Lee K, Wanninkhof R, Bullister J L, Feely R A, Millero F J, Mordy C and Peng T-H 2004 A global ocean carbon climatology: Results from global data analysis project (GLODAP); Global Biogeochem. Cycles $\mathbf{1 8}$ doi:10.1029/2004GB002247.

Lal D, Jull A J T, Pollard D and Vacher L 2005 Evidence for large century time-scale changes in solar activity in the past $32 \mathrm{Kyr}$, based on in-situ cosmogenic ${ }^{14} \mathrm{C}$ in ice at Summit, Greenland; Earth Planet. Sci. Lett. 234 $335-349$.
Lean J, Beer J and Bradley R 1995 Reconstruction of Solar Irradiance since 1610 - Implications for Climate Change; Geophys. Res. Lett. 22 3195-3198.

Meese D A, Gow A J, Alley R B, Zielinski G A, Grootes P M, Ram M, Taylor K C, Mayewski P A and Bolzon J F 1997 The Greenland Ice Project 2 depth-age scale: Methods and results; J. Geophys. Res. 102 26,411-26,424.

Muscheler, Beer R J and Vonmoos M 2004 Causes and timing of the $8200 \mathrm{yr}$ BP event inferred from the comparison of the GRIP ${ }^{10} \mathrm{Be}$ and the tree ring $\Delta^{14} \mathrm{C}$ record; Quat. Sci. Rev. 23 2101-2111.

Morrill C and Jacobsen R M 2005 How widespread were climate anomalies 8200 years ago?; Geophys. Res. Lett. 32 doi:10.1029/2005GL023536.

Neff U, Burns S J, Mangini A, Mudelsee M, Fletmann D and Matter A 2001 Strong coherence between solar variability and the monsoon in Oman between 9 and $6 \mathrm{kyr}$ ago; Nature 411 290-293.

Pang K D and Yau K K 2002 Ancient observations link changes in Sun's brightness and earth's climate; Eos. Am. Geophys. Union 83 489-490.

Rahmstorf S 1995 Bifurcations of the Atlantic thermohaline circulation in response to changes in the hydrological cycle; Nature 378 145-149.

Rasmussen S O et al 2006 A new Greenland ice chronology for the last glacial termination; J. Geophys. Res. 111 doi:10.1029/2005JD006079.

Rohling E J and Palike H 2005 Centennial-scale climate cooling with a sudden cold event around 8,200 years ago; Nature 434 975-979.

Stuiver M and Braziunas T F 1989 Atmospheric ${ }^{14} \mathrm{C}$ and century scale solar oscillations; Nature 338 405-408.

Stuiver M, Reimer P J, Bard E, Beck J W, Burr G S, Hughen K A, Kromer B, McCormac G, Plight J V D and Spurk M 1998 INTCAL98 radiocarbon age calibration, 24,000-0 cal BP; Radiocarbon 40 1041-1083.

Stuiver M, Grootes P M and Braziunas T F 1995 The GISP2 $\delta^{18} \mathrm{O}$ climate record of the past 16,500 years and the role of the sun, ocean, and volcanoes; Quat. Res. 44 341-354.

Summerhayes C P, Emeis K-C, Angel M V, Smith R L and Zeitzschel B 1995 Upwelling in the ocean; Report of Dahlem Workshop Sept. 25-30, 1994, Berlin (John Wiley and Sons) 422.

Worthington L V 1968 Genesis and evolution of water masses; Meteorological Monographs 8 63-67. 